Crops Research Institute for the Semi-Arid Tropics (ICRISAT), Patancheru, 2011, p. 56.

20. Wilson, J. P., Wells, H. D. and Burton, G. W., Inheritance of resistance to Pyricularia grisea in pearl millet accessions from Burkino Faso and inbred Tift 85DB. J. Hered., 1989, 80, 499-501.

21. Klaubauf, S., Tharreau, D., Fournier, E., Groenewald, J. Z., Crous, P. W., Vries, R. P. de and Lebrun, M. H., Resolving the polyphyletic nature of Pyricularia (Pyriculariaceae). Stud. Mycol., 2014, 79, 85-120.

22. Zheng, H. et al., Comparative genomic analysis revealed rapid differentiation in the pathogenicity-related gene repertoires between Pyricularia oryzae and Pyricularia penniseti isolated from a Pennisetum grass. BMC Genomics, 2018, 19, 927.

23. Ngugi, H. K., Julian, A. M., King, S. B. and Peacock, B. J., Epidemiology of sorghum anthracnose (Colletotrichum sublineolum) and leaf blight (Exserohilum turcicum) in Kenya. Plant Pathol., 2000, 49, 129-140.

24. Sutton, B. C., The Coelomycetes, Commonwealth Mycological Institute, Kew, UK, 1980.

25. Thomas, M. D., Sissoko, I. and Sacco, M., Development of leaf anthracnose and its effect on yield and grain weight of sorghum in West Africa. Plant Dis., 1996, 80, 151-153.

26. Narayana, H. S. and Monga, A. K., Antagonism between saprophytic and pathogenic species of Curvularia. Curr. Sci., 1980, 49(18), 713-714.

ACKNOWLEDGEMENT. We thank the Director, ICAR-Central Arid Zone Research Institute, Jodhpur, for providing the necessary research facilities and encouragement.

\section{Fine roots dynamics and biomass of Phyllanthus emblica-based agroforestry system in Bundelkhand region of Central India}

\author{
Dhiraj Kumar ${ }^{1,3, *}$, Ram Newaj ${ }^{1}$, Asha Ram ${ }^{1}$, \\ Rajendra Prasad ${ }^{1}$ and Veeresh Kumar ${ }^{2}$ \\ ${ }^{1}$ ICAR-Central Agroforestry Research Institute, Gwalior Road, \\ Near Pahuj Dam, Jhansi 284 003, India \\ ${ }^{2}$ ICAR-National Bureau of Agricultural Insect Resources, \\ Bengaluru 560 024, India \\ ${ }^{3}$ Present address: ICAR-Indian Institute of Soil Science, \\ Berasia Road, Nabibagh, Bhopal 462 038, India
}

Fine roots are the most important contributors of ecosystem productivity in many terrestrial ecosystems. However, its dynamics, biomass potential, production and turnover rates of fine roots under different envi-

\footnotetext{
*For correspondence. (e-mail: dhiraj.iari@gmail.com)
}

ronments lack clarity. We have studied horizontal and vertical distribution of fine root dynamics, including length, density, biomass, production and turnover rates in Phyllanthus emblica-based agroforestry system in stressed environment of red soil patch of Bundelkhand region in Central India. Nearly, $63 \%$ of the fine root length and its density are confined to 0 $45 \mathrm{~cm}$ soil depth. Fine root biomass significantly varied across seasons with $70-80 \%$ of the biomass obtained during autumn, followed by spring and summer seasons. The annual fine root production rates were highest near the stem base up to $1.0 \mathrm{~m}$ distance and the turnover rates varied from $1.63 \mathrm{yr}^{-1}$ (highest) at $0.5 \mathrm{~m}$ distance to $1.03 \mathrm{yr}^{-1}$ (lowest) at $1.5 \mathrm{~m}$ distance from the stem base. The fine root dynamics changed highly across seasons, indicating more vigorous vegetative growth and nutrient release during monsoon months. Thus, studies on fine root dynamics can improve our understanding of overall system productivity and management under stressed environments.

Keywords: Agroforestry system, fine root biomass, Phyllanthus emblica, turnover rates.

RooTs per se and fine roots in particular act as an integral part of the tree root ecosystem and play a crucial role for better resource acquisition. This in turn improves soil nutrients, organic matter, microbial niche development through their decomposition and turnover. In the improvement of soil health, roots provide carbon and nutrients by rapid turnover, intercept leached nutrients and recycle them to the surface ${ }^{1,2}$. It was observed that in five fruit trees and three forest tree species, nearly $80 \%$ of fine roots were confined to $0-20 \mathrm{~cm}$ soil layer ${ }^{3}$. Fine root biomass and productivity vary under different tree spacings ${ }^{4}$, seasons in the year ${ }^{5}$, intercrops ${ }^{6}$, nutrient level ${ }^{7}$ and soil depth ${ }^{2,3}$. In agroforestry systems, variation in spatial distribution of fine roots is crucial for competition and maximizing the absorption of both soil moisture and nutrients ${ }^{8}$. Thus, studies on fine roots are important in order to decipher belowground competition of resources in intercropped systems.

There are several reports on tree rooting pattern and biomass in the literature ${ }^{9-13}$, but relatively few studies on fine root length or biomass due to the effort involved in its measurement ${ }^{14,15}$. Alterations in fine root growth and its architectural traits may reflect upon the availability of soil resources ${ }^{16}$ and stand characteristics ${ }^{17}$. Thus, the fine roots proliferation within a stand may serve as a useful indicator for assessing stand productivity in reclaimed ecosystems ${ }^{18}$. In terrestrial ecosystems, processes associated with fine root dynamics such as production and turnover are considered to be some of the main drivers of bio-geochemical nutrient cycling and overall stand productivity $^{19-21}$. Nevertheless, fine root turnover may largely dictate, development of potentially long-term $\mathrm{C}$ storage pools in the organic matter of mineral soils ${ }^{22-24}$. Even 
though the importance of fine root dynamics is wellknown, the understanding of its variability temporally as well as spatially is poor. There is paucity of information on processes associated with fine root dynamics across different species or regions.

There is little information on fine root dynamics of long-term stands in the Bundelkhand region of Central India, where the spatial and temporal variation in soil fertility is very high. Considering the above facts, the objective of the present study was to evaluate fine root dynamics, mainly morphometric measurements as fine root length (FRL), fine root length density (FRLD), fine root biomass (FRB) production, and turnover rate in resource-poor tracts of Central India.

The study was undertaken during 2017 at the Experimental Research Farm of ICAR-Central Agroforestry Research Institute, Jhansi, Uttar Pradesh, India. The site is located at $25^{\circ} 30^{\prime} 55.00^{\prime \prime} \mathrm{N}$ lat. and $78^{\circ} 33^{\prime} 10.28^{\prime \prime} \mathrm{E}$ long. at an elevation of $271 \mathrm{~m}$ amsl. The region experiences hot and semi-humid climatic conditions with the hottest days in May and the coldest days in December and January. The mean annual rainfall is around $900 \mathrm{~mm}$, of which $80 \%$ is received during July to September. Actual temperatures are much higher due to local conditions such as absence of fog, and radiation from rocky soils and outcrops. The Phyllanthus emblica (aonla) plantation under study is on red soil patch and Table 1 presents the general stand characteristics. The initial soil $\mathrm{pH}$ was 7.9 , electrical conductivity (EC) was $0.16 \mathrm{~m}$ mhos $\mathrm{cm}^{-1}$, organic carbon was $0.32 \%$, and available nitrogen, phosphorus and potassium was $161.7,13.2$ and $120.6 \mathrm{~kg} \mathrm{ha}^{-1}$ respectively. The understorey crops were mustard (var. RH-749) during rabi 2016-17 and greengram (var. Sweta) during kharif 2017.

The sequential coring method was employed for fine root sampling ${ }^{25}$. The samples were drawn at three

Table 1. Stand characteristics of Phyllanthus emblica-based agroforestry system (AFS)

\begin{tabular}{|c|c|}
\hline Characteristics & $\begin{array}{l}\text { Phyllanthus emblica-based } \\
\text { AFS }\end{array}$ \\
\hline Age (yrs) & 21 \\
\hline Soil type & $\begin{array}{l}\text { Rakar (red soil), Alfisol } \\
(20-58 \%) \text { gravels of } \\
72-80 \mathrm{~mm} \text { size }\end{array}$ \\
\hline Soil texture & Fine sand \\
\hline Stems $\left(\mathrm{ha}^{-1}\right)$ & 100 \\
\hline Crown spread (m) & $8.28 \pm(1.59)$ \\
\hline Height (m) & $6.33 \pm(0.76)$ \\
\hline Collar diameter $(\mathrm{cm})$ & $27.60 \pm(8.77)$ \\
\hline Tree basal area $\left(\mathrm{m}^{2}\right)$ & $0.06 \pm(0.04)$ \\
\hline Stand basal area $\left(\mathrm{m}^{2} \mathrm{ha}^{-1}\right)$ & $5.98 \pm(3.87)$ \\
\hline Standing volume $\left(\mathrm{m}^{3} \mathrm{ha}^{-1}\right)$ & $37.90 \pm(30.82)$ \\
\hline Mean annual increment $\left(\mathrm{m}^{3} \mathrm{ha}^{-1} \mathrm{yr}^{-1}\right)$ & $1.80 \pm(1.47)$ \\
\hline *Total biomass (above + below) $\left(\mathrm{t} \mathrm{ha}^{-1}\right)$ & $21.27 \pm(8.69)$ \\
\hline
\end{tabular}

Figures in parenthesis represent \pm standard deviation, $n=3$.

*The allometric equation used for total biomass estimation is adapted from Newaj et al. ${ }^{42}$. intervals, viz. March, June and October representing spring, summer and autumn respectively. Soil cores were extracted from soil using a power auger $(9.0 \mathrm{~cm}$ diameter). Each core was kept separate in polythene bags and brought back to the laboratory for subsequent washing, segregation and characterization on the same day of sampling. Soil cores were sampled from six different depths $(0-15,15-30,30-45,45-60,60-75$ and $75-90 \mathrm{~cm})$ at $0.5,1.0,1.5,2.0,2.5$ and $3.0 \mathrm{~m}$ distance from the stem base respectively. Soil coring was done randomly around the tree base in any direction and two samples were drawn subsequently from each depth.

Roots from the cores were separated from the soil by subsequent washing with tap water. The samples were soaked overnight, poured into trays and rubbed gently. Roots floating on top of the water were collected by pouring water over sieves with mesh size ranging from 5 to $0.5 \mathrm{~mm}$ (ref. 26). Roots $<2 \mathrm{~mm}$ in diameter were considered as fine roots ${ }^{2}$. The procedure was repeated till all organic or rock debris were removed from the soil. The live and dead roots separation was difficult, thus root mass in this study includes both live and dead roots. The cleaned roots were scanned using a flatbed scanner Biovis Root Analyser (Expression 12000 XL EPSON, Expert Vision, Mumbai, India). The root images were analysed to determine FRL. FRLD was calculated by dividing total root length per core by total volume of the core.

Fine roots collected along different distances from the stem base and from various depths were washed thoroughly in clean water and oven-dried at $70^{\circ} \mathrm{C}$ to constant weight and then weighed $\left(\mathrm{gm}^{-2}\right)$. Fine root production was estimated in $0-90 \mathrm{~cm}$ depth through sequential coring (minimum-maximum) method $^{27}$. The present study computes the minimum and maximum difference of fine root biomass in the process and further equates it with fine root production. Fine root turnover rate was calculated by dividing annual fine root production with the mean fine root mass $\left(\mathrm{yr}^{-1}\right)^{28}$. The data were assessed for analysis of variance to determine statistical significance of treatment effects.

FRL differed widely across various soil depths and distances from the stem base (Figure 1). The mean FRL across 0-90 cm soil depth ranged from $31.75 \mathrm{~cm}$ at 75 $90 \mathrm{~cm}$ soil depth to $97 \mathrm{~cm}$ at $0-15 \mathrm{~cm}$ soil depth. On an average, almost $63 \%$ of the FRL was confined to 0 $45 \mathrm{~cm}$ soil depth. Subsequently, across different distances from tree base, FRL varied from $34.84 \mathrm{~cm}$ at $3.0 \mathrm{~m}$ to $101.44 \mathrm{~cm}$ at $2.0 \mathrm{~m}$ distance from the stem base (Figure 1). Further, the distribution of FRLD had similar pattern as to that of FRL in $0-45 \mathrm{~cm}$ soil depth (Figure 2). However, the variation of FRLD was from $0.0365 \mathrm{~cm} \mathrm{~cm}^{-3}$ at $3.0 \mathrm{~m}$ distance to $0.1065 \mathrm{~cm} \mathrm{~cm}^{-3}$ at $2.0 \mathrm{~m}$ distance from the stem base.

In this study, FRL and FRLD varied across distance and soil depth of $P$. emblica-based agroforestry system. Considering soil depth, it was observed that around $63 \%$ 
of FRL and FRLD were confined to $0-45 \mathrm{~cm}$ soil depth across different distances from the stem base (Figures 1 and 2), as was also concluded by Bi et al. ${ }^{29}$.

However, FRL variation was evident across all depths studied $(0-90 \mathrm{~cm})$ and also across different distances from the tree base $(0.5-3.0 \mathrm{~m})$, because of the variable distribution of moisture and nutrients, and also proliferation of fine roots to deeper soil layers in tree-crop interactions. In the present study, the red soil patch was very poor with respect to moisture and physico-chemical soil properties, which further led to skewed distribution of fine roots. Our results also support the findings that in the arid and semi-arid regions of the Loess Plateau, water is the primary limiting factor for plant growth, and soil nutrients on farmland are insufficient ${ }^{30}$.

The standing FRB showed maximum proliferation in top $0-45 \mathrm{~cm}$ soil depth and the corresponding values ranging across various distances from the stem base $(0.5$, $1.0,1.5,2.0,2.5$ and $3.0 \mathrm{~m}$ ) were found to be $77 \%, 70 \%$, $60 \%, 46 \%, 72 \%$ and $65 \%$ respectively (Figure 3). Furthermore, across seasons, FRB increased during monsoon and subsequently decreased till summer. Of the total FRB obtained across different seasons, nearly $70-80 \%$ was obtained in autumn and the rest in spring and summer seasons. At $0.5 \mathrm{~m}$ distance from the stem base, mean FRB across seasons varied from $7.11 \mathrm{~g} \mathrm{~m}^{-2}$ in summer to $18.26 \mathrm{~g} \mathrm{~m}^{-2}$ in spring to $50.81 \mathrm{~g} \mathrm{~m}^{-2}$ in autumn (Figure 3 ). At $1.0 \mathrm{~m}\left(7.49,8.18\right.$ and $\left.64.4 \mathrm{~g} \mathrm{~m}^{-2}\right), 1.5 \mathrm{~m} \mathrm{(4.6,13.9} \mathrm{and}$ $\left.47.23 \mathrm{~g} \mathrm{~m}^{-2}\right), 2.0 \mathrm{~m}\left(1.6,8.49\right.$ and $\left.42.97 \mathrm{~g} \mathrm{~m}^{-2}\right), 2.5 \mathrm{~m}$ $\left(4.72,6.42\right.$ and $\left.49.93 \mathrm{~g} \mathrm{~m}^{-2}\right)$ and $3.0 \mathrm{~m}(2.33,10.25$ and $31.27 \mathrm{~g} \mathrm{~m}^{-2}$ ) from the stem base, these corresponding values of FRB for summer, spring and autumn respectively are given within brackets. Thus, the general trend for FRB estimation across seasons follows the order: autumn $>$ spring $>$ summer.

Seasonal maximum FRB range from $79 \pm 2.6 \mathrm{~g} \mathrm{~m}^{-2}$ at $3.0 \mathrm{~m}$ distance to $152 \pm 2.6 \mathrm{~g} \mathrm{~m}^{-2}$ at $0.5 \mathrm{~m}$ distance from the stem base (Table 2). While minimum FRB ranged from $18+0.7 \mathrm{~g} \mathrm{~m}^{-2}$ at $2.0 \mathrm{~m}$ distance to $32 \pm 1.1 \mathrm{~g} \mathrm{~m}^{-2}$ at $2.5 \mathrm{~m}$ distance. Across different distances from the stem base, $58 \%$ of mean FRB was confined to $1.5 \mathrm{~m}$ distance from the stem base. Production rates of fine roots were high within $1.0 \mathrm{~m}$ distance from the stem base with values of $124 \mathrm{~g} \mathrm{~m}^{-2} \mathrm{yr}^{-1}$ at $0.5 \mathrm{~m}$ and $95 \mathrm{~g} \mathrm{~m}^{-2} \mathrm{yr}^{-1}$ at $1.0 \mathrm{~m}$. The annual fine root production rates were high near to the stem base, indicating availability of moisture and nutrients. The fine root turnover rates ranged from $1.03 \mathrm{yr}^{-1}$ at $1.5 \mathrm{~m}$ distance to $1.63 \mathrm{yr}^{-1}$ at $0.5 \mathrm{~m}$ distance (Table 2).

Majority of nutrient and moisture uptake from the soil happens through fine roots as they have a large surface area. FRB of $P$. emblica in this study pertain to $60-70 \%$ of proliferation in $0-45 \mathrm{~cm}$ soil depth (Figure 3 ). The vertical distribution of FRB is in agreement with other stu$\operatorname{dies}^{31,32}$. There was more proliferation of FRB in the surface than subsurface layers ${ }^{33}$, but this study is different in regard to FRB extension to even deeper layers and extending horizontally as well. However, fine root concentrated in the topsoil layers. Due to fragile soils, harsh conditions and sloping nature of the site, the system was susceptible to nutrient loss ${ }^{34}$, leaching, etc. This was reflected in the fine root proliferation both horizontally and vertically in the study. We found a clear effect of distance from the stem base on FRB, nearly $58 \%$ of FRB was found within $1.5 \mathrm{~m}$ distance (Table 2). FRB distribution close to the stem corresponds to availability of water and nutrients $^{3,35}$. We observed distinct pattern of FRB dynamics seasonally, with highest FRB obtained in autumn (warm and humid) followed by spring and summer, in conformity with other studies ${ }^{3,36-38}$. This coincides with proliferation of vigorous vegetative growth stage and period of nutrient release. The findings would help frame/ schedule nutrient application timing in agroforestry systems, mainly due to high rate of leaching when the roots are not deep and active. The low FRB during spring might be due to the high demand of food for initiation of new leaves or branches that led to translocation of foods from the root towards the shoot.

We studied FRB production rates as well as turnover and the high values of both near the stem might be attributed to the availability of nutrients and moisture around the stem $^{39}$. The turnover rates ranged from $1.03 \mathrm{yr}^{-1}$ at

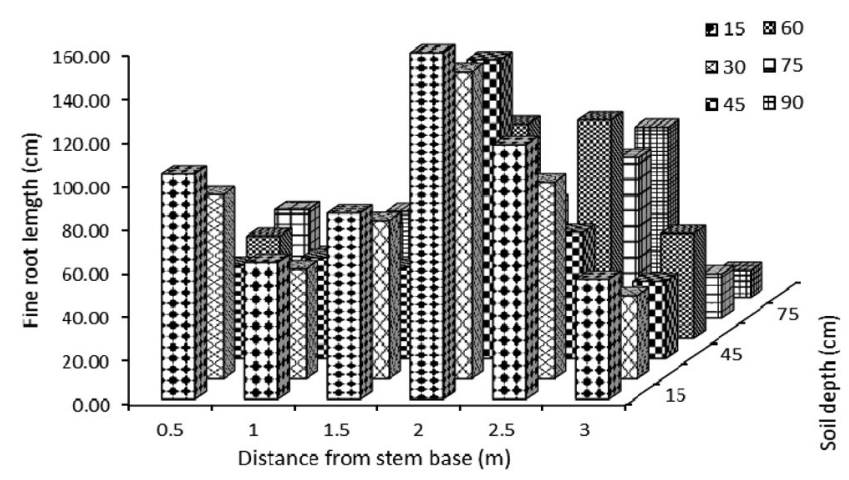

Figure 1. Distribution of annual mean fine root length $(\mathrm{cm})$ at soil depths of $0.5,1.0,1.5,2.0,2.5$ and $3.0 \mathrm{~m}$ from the stem base of Phyllanthus emblica.

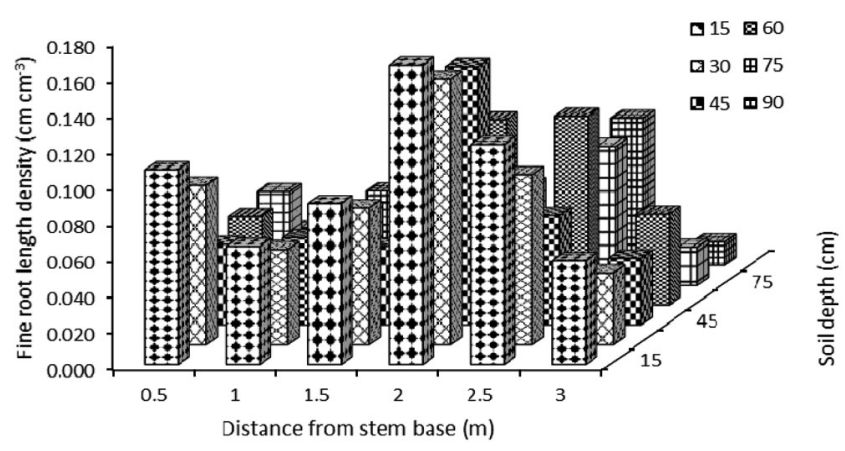

Figure 2. Distribution of annual mean fine root length density (cm $\mathrm{cm}^{-3}$ ) at soil depths of $0.5,1.0,1.5,2.0,2.5$ and $3.0 \mathrm{~m}$ from the stem base of $P$. emblica. 

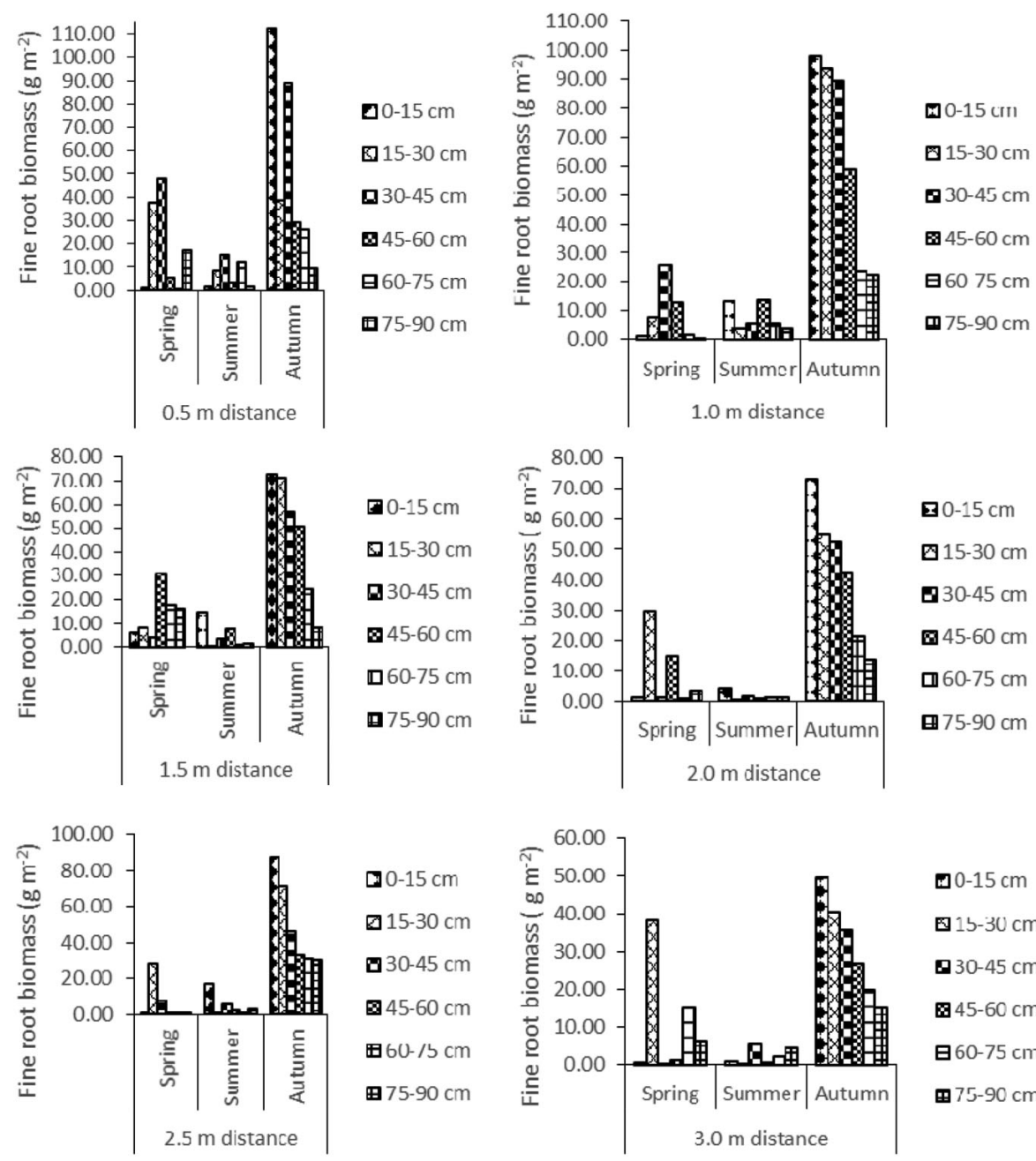

0-15 cm

๑15-30 cm

- $30-45 \mathrm{~cm}$

จ $45-60 \mathrm{~cm}$

田60-/b cm

田75-90 cm



Figure 3. Fine root biomass distribution $\left(\mathrm{g} \mathrm{m}^{-2}\right)$ at soil depths of $0.5,1.0,1.5,2.0,2.5$ and $3.0 \mathrm{~m}$ from the stem base in P. emblica.

Table 2. Seasonal fine root biomass (FRB) (mean \pm SD), mean FRB, annual fine root production and annual turnover rate of fine roots along six distances from stem base in $0-90 \mathrm{~cm}$ soil depth

\begin{tabular}{lccccc}
\hline \multirow{2}{*}{$\begin{array}{l}\text { Distance (from } \\
\text { stem base, } \mathrm{m})\end{array}$} & \multicolumn{2}{c}{ Seasonal FRB $\left(\mathrm{g} \mathrm{m}^{-2}\right)$} & & & \\
\cline { 2 - 5 } & Maximum & Minimum & $\begin{array}{c}\text { Mean FRB } \\
\left(\mathrm{g} \mathrm{m}^{-2}\right)\end{array}$ & $\begin{array}{c}\text { Production } \\
\left(\mathrm{g} \mathrm{m}^{-2} \mathrm{yr}^{-1}\right)\end{array}$ & $\begin{array}{c}\text { Turnover rate } \\
\left(\mathrm{yr}^{-1}\right)\end{array}$ \\
\hline 0.5 & $152 \pm 2.6^{\mathrm{f}}$ & $28 \pm 1.1^{\mathrm{b}}$ & 76 & 124 & 1.63 \\
1.0 & $121 \pm 2.9^{\mathrm{e}}$ & $26 \pm 0.5^{\mathrm{b}}$ & 80 & 95 & 1.18 \\
1.5 & $93 \pm 20^{\mathrm{c}}$ & $26 \pm 3.2^{\mathrm{b}}$ & 66 & 68 & 1.03 \\
2.0 & $85 \pm 1.1^{\mathrm{b}}$ & $18 \pm 0.7^{\mathrm{a}}$ & 53 & 68 & 1.28 \\
2.5 & $105 \pm 0.7^{\mathrm{d}}$ & $32 \pm 1.1^{\mathrm{c}}$ & 61 & 74 & 1.21 \\
3.0 & $79 \pm 2.6^{\mathrm{a}}$ & $26 \pm 0.3^{\mathrm{b}}$ & 44 & 53 & 1.20 \\
\hline
\end{tabular}

Mean values with different superscripts at increasing distances from the tree base are significantly different at $P<0.05$ between sampling points. Mean values with the same superscripts at increasing distances from the stem base are not significantly different at $P<0.05$ between sampling points.

$1.5 \mathrm{~m}$ and $1.63 \mathrm{yr}^{-1}$ at $0.5 \mathrm{~m}$ distance, and the value obtained is well within the values reported from tropical sites, i.e. 0.3 to $2.5 \mathrm{yr}^{-1}$ (refs 39,40 ). The root turnover increases in warmer climate due to increase in maintenance respiration, i.e. respiratory energy required for all processes of plants, thus reducing average lifespan.
The values vary widely from boreal to tropical zones. This might reflect the influence of seasonality on root turnover, implying that in order to maintain the same belowground biomass as temperate or boreal systems, tropical zones require a higher belowground productivity ${ }^{41}$. 
The results may be conducive in order to understand FRB and its production for carbon accumulation in the current scenario.

The present study deals with both spatial and temporal variation of fine root dynamics across different seasons, depths and distances from the stem base as well as annual FRB, production and its turnover rate. The results suggest, that FRLD and biomass are higher in the top 0$45 \mathrm{~cm}$ soil layer. However, FRB extracted during autumn is comparatively higher over spring and summer seasons. Overall, annual production rates and turnover are maximum near the stem base, although the fine roots were distributed farther from the stem base as well. The fine roots help in the acquisition of moisture and nutrient and move longer distances from the stem base under stressed environment, as evidenced in the study. Understanding of fine roots dynamics under different climatic and edaphic conditions is quite necessary for researchers, as these are the storehouse of agroforestry system productivity. Further, studies on fine root dynamics in association with soil microflora and under stressed conditions are necessary to strengthen our understanding of belowground dynamics.

1. Tufekcioglu, A., Raich, J. W., Isenhart, T. M. and Schultz, R. C., Fine root dynamics, coarse root biomass, root distribution, and soil respiration in a multi-species riparian buffer in Central Iowa, USA. Agrofor. Syst., 1999, 44, 163-174.

2. Dhyani, S. K. and Tripathi, R. S., Biomass and production of fine and coarse roots of trees under agrisilvicultural practices in northeast India. Agrofor. Syst., 2000, 50, 107-121.

3. Raizada, A., Jayaprakash, J., Rathore, A. C. and Tomar, J. M. S., Distribution of fine root biomass of fruit and forest tree species raised on old river bed lands in the North West Himalaya. Trop. Ecol., 2013, 54, 251-261.

4. Singh, V., Root distribution in Populus deltoides 'G-3' plantations in an arid region of north-western India. Trop. Ecol., 1994, 35, 105-113.

5. Cavelier, J., Wright, S. J. and Santamaria, J., Effects of irrigation on litterfall, fine root biomass and production in a semi deciduous lowland forest in Panama. Plant Soil, 1999, 211, 207-213.

6. Smith, D. M., Jackson, N. A., Roberts, J. M. and Ong, C. K., Root distributions in a Grevillea robusta maize agroforestry system in semi-arid Kenya. Plant Soil, 1999, 211, 191-205.

7. Nadelhoffer, K. J., The potential effects of nitrogen deposition on fine-root production in forest ecosystems. New Phytol., 2000, 147, $131-139$.

8. Duan, Z. P., Gan, Y. W., Wang, B. J., Hao, X. D., Xu, W. L., Zhang, W. and Li, L. H., Interspecific interaction alters root morphology in young walnut/wheat agroforestry systems in northwest China. Agrofor. Syst., 2017, 93, 219-221.

9. Toky, O. P. and Bisht, R. P., Observations on the rooting patterns of some agroforestry trees in an arid region of north-western India. Agrofor. Syst., 1992, 17, 245-263.

10. Schroth, G., Tree root characteristics as criteria for species selection and system design in agroforestry. Agrofor. Syst., 1995, 30, $125-143$.

11. Akinnifesi, F. K., Kang, B. T. and Ladipo, D. O., Structural root form and fine root distribution of some woody species evaluated for agroforestry systems. Agrofor. Syst., 1999, 42, 121-138.

12. Chaturvedi, O. P. and Das, D. K., Studies on rooting patterns of 5year-old important agroforestry tree species in North Bihar, India. For. Trees Livelihood, 2002, 12, 329-339.
13. Dossa, E. L., Fernandes, E. C. M., Reid, W. S. and Ezui, K., Above and belowground biomass, nutrient and carbon stocks contrasting an open-grown and a shaded coffee plantation. Agrofor. Syst., 2008, 72, 103-117.

14. Jones, M., Sinclair, F. L. and Grime, V. L., Effect of tree species and crown pruning on root length and soil water content in semiarid agroforestry. Plant Soil, 1998, 201, 197-207.

15. Chesney, P., Nitrogen and fine root length dynamics in a tropical agroforestry system with periodically pruned Erithrina poeppigiana. Agrofor. Syst., 2008, 72, 149-159.

16. Rosenvald, K., Kuznetsova, T., Ostonen, I., Truu, M., Truu, J., Uri, V. and Lohmus, K., Rhizosphere effect and fine-root morphological adaptations in a chronosequence of silver birch stands on reclaimed oil shale post-mining areas. Ecol. Eng., 2011, 37, 10271034.

17. Jung, K. and Chang, S. X., Soil and tree chemistry reflected the cumulative impact of acid deposition in Pinus banksiana and Populus tremuloides stands in the Athabasca oil sands region in western Canada. Ecol. Indic., 2013, 25, 35-44.

18. Gilroy, S. and Jones, D. L., Through form to function: root hair development and nutrient uptake. Trends Plant Sci. Rev., 2000, 5, 56-60.

19. Yuan, Z. and Chen, H. Y., Effects of disturbance on fine root dynamics in the boreal forests of northern Ontario, Canada. Ecosystems, 2013, 16, 467-477.

20. Gundale, M. J., Kardol, P., Nilsson, M., Nilsson, U., Lucas, R. W. and Wardle, D. A., Interactions with soil biota shift from negative to positive when a tree species is moved outside its native range. New Phytol., 2014, 202, 415-421.

21. Tripathi, N., Singh, R. S. and Nathanail, C. P., Mine spoil acts as a sink of carbon dioxide in Indian dry tropical environment. Sci. Total Environ., 2014, 468, 1162-1171.

22. Richter, D. D., Markewitz, D., Trumbore, S. E. and Wells, C. G., Rapid accumulation and turnover of soil carbon in a re-establishing forest. Nature, 1999, 400, 56-58.

23. Rasse, D. P., Rumpel, C. and Dignac, M. F., Is soil carbon mostly root carbon? Mechanisms for a specific stabilisation. Plant Soil, 2005, 269, 341-356.

24. Tefs, C. and Gleixner, G., Importance of root derived carbon for soil organic matter storage in a temperate old-growth beech forest-evidence from C, N and C-14 content. For. Ecol. Manage., 2012, 263, 131-137.

25. Vogt, K. A. and Persson, H., Measuring growth and development of roots. In Techniques and Approaches in Forest Tree Ecophysiology (eds Lassoie, J. P. and Hinckley, T. M.), CRC Press, Boca Raton, FL, USA, 1991.

26. Anderson, J. M. and Ingram, J. S. I., Tropical Soil Biology and Fertility: A Handbook of Methods, CAB International, Wallingford, UK, 1993.

27. McClaugherty, C. A., Aber, J. D. and Melillo, J. M., The role of fine roots in the organic matter and nitrogen budgets of two forested ecosystems. Ecology, 1982, 63, 1481-1490.

28. Jha, P. and Mohapatra, K. P., Leaf litter fall, fine root production and turnover in four major tree species of the semi arid region of India. Plant Soil, 2010, 326, 481-491.

29. Bi, H. X., Yun, L. and Zhu, Q. K., Study on the Interspecific Relationships of Agroforestry Systems in the Loess Area of Western Shanxi Province, Science Press, Beijing, China, 2011, pp. 20-109.

30. Zhu, Q. K. and Zhu, J. Z., Sustainable Management Technology for Conversion of Cropland to Forest in Loess Area, Chinese Forestry Press, Beijing, China, 2003, pp. 179-186.

31. Bennett, J. N., Andrew, B. and Prescott, C. E., Vertical fine root distributions of western red cedar, western hemlock, and salal in old-growth cedar-hemlock forests on northern Vancouver Island. Can. J. For. Res., 2002, 32, 1208-1216.

32. Siles, P., Harmand, J. M. and Vaast, P., Effects of Inga densiflora on the microclimate of coffee (Coffea Arabica L.) and overall 
biomass under optimal growing conditions in Costa Rica. Agrofor. Syst., 2010, 78, 269-286.

33. Bakker, M. R., Augusto, L. and Achat, D. L., Fine root distribution of trees and understory in mature stands of maritime pine (Pinus pinaster) on dry and humid sites. Plant Soil, 2006, 286, 37-51.

34. Pei, Y., Lei, P., Xiang, W., Ouyang, S. D. and Xu, Y., Effect of stand age on fine root biomass, production and morphology in Chinese fir plantations in subtropical China. Sustainability, 2018, 10(7), 2280

35. Vitousek, P. M. and Sanford Jr, R. L., Nutrient cycling in moist tropical forest. Annu. Rev. Ecol. Syst., 1986, 17, 137-167.

36. Taugourdeau, S. et al., Leaf area index as an indicator of ecosystem services and management practices: an application for coffee agroforestry. Agric. Ecosyst. Environ., 2014, 192, 19-37.

37. Khiewtam, R. S. and Ramakrishnan, P. S., Litter and fine roo dynamics of a relic sacred grove forest at Cherrapunji. For. Ecol. Manage., 1993, 60, 327-344.

38. Upadhaya, K., Pandey, H. N., Law, P. S. and Tripathi, R. S., Dynamics of fine and coarse roots and nitrogen mineralization in a humid subtropical forest ecosystem of north east India. Biol. Fertil. Soils, 2005, 41, 144-152.

39. King, J. S., Albaugh, T. J., Allen, H. L., Buford, M., Strain, B. R. and Dougherty, P., Below-ground carbon input to soil is controlled by nutrient availability and fine root dynamics in loblolly pine. New Phytol., 2002, 154, 389-398.

40. Silver, W. L. et al., Fine root dynamics and trace gas fluxes in two lowland tropical forest soils. Global Change Biol., 2005, 11, 290360 .

41. Gill, R. A. and Jackson, R. B., Global patterns of root turnover for terrestrial ecosystems. New Phytol., 2000, 147, 13-31.

42. Newaj, R., Chavan, S. B., Alam, B. and Dhyani, S. K., Biomass and carbon storage in trees grown under different agroforestry systems in semi arid region of Central India. Indian For., 2016, 142(7), 642-648.

ACKNOWLEDGEMENTS. We thank the Indian Council of Agricultural Research (ICAR), New Delhi and ICAR-Central Agroforestry Research Institute, Jhansi for providing funds. We also thank our colleagues for cooperation and help during the course of this study.

Received 15 April 2020; accepted 23 September 2020

\section{Why primary processing of herbal raw drugs is important}

\author{
Vinod K. Bisht ${ }^{1, *}$ and Ramesh C. Uniyal ${ }^{2}$ \\ ${ }^{1}$ Zandu Foundation for Health Care, Ambach, Pardi 396 145, India \\ ${ }^{2}$ Bioresources Development, Emami Ltd, 687, Anandapur, \\ EM Bypass, Kolkata 700 107, India
}

The present study was carried out to analyse foreign matter (FM) in herbal raw drugs (HRDs), as it deteriorates the quality and therapeutic efficacy of the endproduct. A total of 35 HRDs representing 11 different parts were analysed. For each drug, 3-8 samples with each sample having 5-500 $\mathrm{kg}$ of drugs were collected. The FM was found to vary from $2.59 \%$ to $47.48 \%$, and none of the drugs complied with the parameters of Ayurvedic Pharmacopoeia of India (API). Nearly $\mathbf{4 8 . 5 7 \%}$ of the drugs in the Indian market are traded with more than $10 \%$ of $F M$ in them. The FM in most of the drugs is contributed by components other than official drugs of the same species. The quality of raw drugs can be enhanced by making them free of FM or reducing it to the permissible limits of $A P I$, with the execution of good agriculture and collection practices and good field collection practices. Proper supply chain management of quality raw drugs may be assured by developing infrastructure like establishment of new and strengthening of existing mandis (herbal collection and retail/wholesale outlets) having post-harvest processing facilities. Measures like, linkages between farmers and buyers, and buy-back interventions through on-line virtual platforms such as e-charak and e-NAM must also be taken into consideration. In conclusion, a comprehensive nationallevel policy/strategy is needed to address various issues pertaining to the quality and marketing of HRDs.

Keywords: Foreign matter, herbal raw drugs, market linkages, medicinal plants, post-harvest management.

IN India, 1622 herbal raw drugs (HRDs) belonging to 1178 medicinal plants are in commercial trade ${ }^{1}$. The official accepted HRDs comprise of root, rhizome, bark, stem, leaf, flower, fruit, fruit rind, seed, heartwood, aerial part, whole plant, gum, resin, etc. The total estimated consumption of HRDs is 512,000 MT, with corresponding trade value of ₹7000 crore for 2014-15 (ref. 1). Out of 1178 species, 242 are traded in quantities exceeding $100 \mathrm{MT}$ per year. HRDs belonging to 198 species account for about $95 \%$ of the total such drugs consumed by India's herbal industry ${ }^{1}$. In the last two decades, the Indian herbal sector has witnessed an annual growth of $>10 \%$ and is emerging as a major economic activity ${ }^{2}$.

With growing recognition for these resources, the herbal industries require large quantities of HRDs. This

*For correspondence. (e-mail: vksbisht@gmail.com) 